\title{
Effect of dietary substitution of fish oil by Echium oil on growth, plasma parameters and body lipid composition in gilthead seabream (Sparus aurata L.).
}

\author{
${ }^{1}$ Mercedes Díaz-López, ${ }^{1} \mathbf{M}^{\mathrm{a}}$ José Pérez, ${ }^{1}$ Nieves Guadalupe Acosta, ${ }^{3}$ Douglas R. Tocher, \\ ${ }^{2}$ Salvador Jerez, ${ }^{1}$ Antonio Lorenzo, ${ }^{1 \&}$ Covadonga Rodríguez \\ ${ }^{1}$ Departamento de Biología Animal (U.D.I. Fisiología Animal), Facultad de Biología, Universidad \\ de La Laguna, La Laguna, 38206, Spain \\ ${ }^{2}$ Centro Oceanográfico de Canarias (I.E.O.), Crta. de San Andrés s/n, 38120 S/C de Tenerife, Spain \\ ${ }^{3}$ Institute of Aquaculture, University of Stirling, Stirling FK9 4LA, Scotland, United Kingdom.
}

Key Words: Sparus aurata, development, Echium oil, GLA, SDA, body lipids.

Running Title: Echium oil and gilthead seabream development and body composition.

${ }^{\&}$ Corresponding author:

Covadonga Rodríguez González

Laboratorio de Fisiología Animal, Departamento de Biología Animal, Facultad de Biología, Universidad de La Laguna, La Laguna, 38206, Tenerife, SPAIN

Tel: 0034-922-318339/37

Fax: 0034-922-318311

E-mail address: covarodr@ull.es 


\begin{abstract}
Gilthead seabream juveniles were fed on either a fish oil (FO)-containing diet or a diet containing a 50:50 blend of FO and Echium oil (EO) to determine the effect of EO on growth, plasma parameters and tissue lipid compositions. After 4 months of feeding, there was a significant increase of $18: 2 n-6$ and a reduction of around $25 \%$ of $20: 5 n-3$ in flesh of the fish fed the EO diet. At this point, half of the fish fed EO were returned to the FO diet as a third treatment $(\mathrm{EF})$ and the trial continued with the three groups for a further 3 months. At the end of the experiment, food intake, survival, growth and plasma parameters were not affected by the inclusion of dietary EO. However, HSI, total lipid and triacylglycerol contents of muscle decreased in fish fed the EO diet. Feeding the EO diet resulted in significant increments of potentially health-promoting fatty acids such as $18: 3 n-6,18: 4 n-3$ and $20: 3 n-6$ but reduced n-3 highly unsaturated fatty acids, particularly $20: 5 n-3$. When EO-fed fish were returned to the FO diet, tissue lipid contents and HSI tended to increase, but 18:2n-6 and 20:5n-3 levels were not fully restored to the levels of fish fed the FO diet for the entire trial. Furthermore, the fatty acids present in EO, which may promote beneficial health effects, were reduced.
\end{abstract}




\section{Introduction}

Omega-3 (n-3) highly unsaturated fatty acids (HUFA) are important dietary nutrients for mammals including humans (Simopoulos, 2000), and fish are the major dietary source of these physiologically essential fatty acids (Ackman, 1980; Sargent and Tacon, 1999). In the course of just a few decades, fish farming has developed into a highly productive and efficient industry for the production of animal protein and oil for human consumption (FAO, 2004). Diets for the major carnivorous finfish species farmed in Europe have traditionally been based on fish meal and fish oil (FO) (Sargent and Tacon, 1999; Tacon, 2004). The development of oil-rich high-energy feeds to obtain increased productivity and economic sustainability of fish farming, together with the general growth of the aquaculture industry has led to a significant proportion of global FO production being used for fish feed. In fact, $100 \%$ of the world's total FO production is estimated to be required for feed production by the year 2010 (New, 1999). Moreover, "El Niño" phenomena clearly demonstrated the impact a shortage of FO can have on raw material prices and thus on feed prices and overall farming economy (Sargent and Tacon, 1999). As a consequence, the sustainable development of aquaculture requires dietary FO to be replaced, with vegetable oils (VO) as the primary alternatives (Sargent et al., 2002). Supplies of VOs are around 100 times higher than FO (Bimbo, 1990), and production continues to increase, and their prices remain constant. Furthermore, using FO can produce accumulation of toxic contaminants including dioxins and PCBs in the flesh and so fish fed with VOs considerably reduced levels of contaminants (Bell et al., 2005; Drew et al., 2007).

Gilthead seabream, Sparus aurata L., is the most important marine fish species in Mediterranean and Canarian aquaculture. This species can generally be grown well on diets in which the FO has been partially replaced with VO (Montero et al., 2003; Izquierdo et al., 2005). However, although incorporation of VO in fish diets has minimal effects on fish growth it significantly influences the nutritional quality of flesh in salmonids (Sargent et al., 
2002) as well as in marine fish including gilthead seabream (Montero et al., 2005), seabass (Montero et al., 2005) and Atlantic cod (Bell et al., 2006). The modification of flesh when feeding marine fish with VO is reflected in increased tissue total lipids (Kalogeropulos et al., 1992; Menoyo et al., 2004) and, particularly, $\mathrm{C}_{18}$ polyunsaturated fatty acids (PUFA) such as linoleic acid (LA; 18:2n-6) and linolenic acid (LNA; 18:3n-3) as well as reduced levels of the n-3 HUFA, eicosapentaenoic (EPA; 20:5n-3) and docosahexaenoic (DHA; 22:6n-3) acids (Sargent et al., 2002), which potentially compromise its nutritional quality for consumers (Bell et al., 2001; Sargent et al., 2002). Nowadays, the Western diet contains far more n-6 than n-3 fatty acids, and an excess of 18:2n-6 has been associated with neurodegenerative and cardiovascular diseases and some cancers (Okuyuma et al., 1997; Horia and Watkins, 2005). The changes in the fatty acid profile of flesh are partly due to the inability of marine fish to convert 18:2n-6 and 18:3n-3 from VO to arachidonic acid (ARA; 20:4n-6) and EPA/DHA, respectively, at a physiologically significant rate (Sargent et al., 2002). Therefore, the HUFA are essential fatty acids (EFA) for marine fish and are particularly important, not only as structural components of cell membranes, but also as precursors of eicosanoids (prostaglandins, leukotrienes etc.), which are involved in many physiological processes, including homeostasis, osmoregulation, immune and inflammatory responses and reproduction (Bell et al., 1994, 1997). Therefore, replacement of FO is only possible when HUFA are present in the diet at sufficient quantities to meet the EFA requirements of the fish. As a consequence, diets formulated with VO substitutes should avoid excessive 18:2n-6 and retain sufficient levels of HUFA, and maximize any potential for conversion of $18: 3 n-3$ to $20: 5 n-3$ and $22: 6 n-3$. A further strategy to minimise the negative effects of deposition of VO fatty acids in flesh, and to produce fish fillets with a high content of n-3 HUFA, is to utilize a "finishing" period, where fish are returned to fish oil diets to promote recovery of the diminished n-3 HUFA and reduce the 18:2n-6 accumulated in flesh. 
In the Echium genus (Boraginaceae), seed oils are relatively rich in n-3 fatty acid such as $18: 3 n-3$ and $18: 4 n-3$ (stearidonic acid, SDA) and n-6 fatty acids such as $18: 3 n-6(\gamma-$ linolenic acid, GLA), with only moderate levels of 18:2n-6 compared to other VOs (GuilGuerrero et al., 2000a,b). Thus, Echium oil (EO) has an extremely interesting profile since the unusual fatty acids SDA and GLA have a growing pharmacological interest based on their competitive and inhibitory effects in the production of proinflammatory eicosanoids derived from ARA (Sayanova and Napier, 2004). Specifically, the $\mathrm{C}_{20}$ elongation products of SDA and GLA, 20:4n-3 and 20:3n-6 respectively, compete with ARA in the synthesis of eicosanoids and reduce production of eicosanoids from ARA (Weber, 1990; Ghioni et al., 2002). They also generate their own eicosanoids which, together with eicosanoids produced from EPA, play important roles in the regulation of many physiological and immunological body processes (Balfry and Higgs, 2001), being particularly produced in response to stressful situations (Sargent et al., 1999). Recent studies have shown inhibition of ARA prostaglandin production in fish fed with EO (Bell et al., 2006; Villalta et al., 2007). The high levels SDA and GLA, compared to LNA and LA, could facilitate their conversion into n-3 and n-6 HUFA, as their conversion does not require the first, rate-limiting, $\Delta 6$-desaturation step, which may also be advantageous.

The present study aims to determine if up to half of the n-3 HUFA currently used in feeds for gilthead seabream could be replaced by the n-3 and n- 6 fatty acids present in EO, without significantly compromising the health and growth performance of the fish, or its body composition and health promoting characteristics. To this purpose, fish survival, growth, plasma parameters and lipid and fatty acid composition of muscle and liver were determined in gilthead seabream fed either a diet formulated with FO or a diet in which $50 \%$ of the FO was substituted with EO. 


\section{Material and methods}

\subsection{Animal and diets}

A feeding experiment was conducted using gilthead seabream (Sparus aurata L.) juveniles obtained from a local fish farm (Cedra S.L.L.) and maintained for seven months at the Centro Oceanográfico de Canarias (Instituto Español de Oceanografía, Tenerife, Spain). Fish with an initial average weight of $265.05 \pm 49.75 \mathrm{~g}$ were divided into six 500L circular tanks with 14 fish per tank, and reared under constantly flowing seawater. The fish were subjected to natural photoperiod and water temperature which ranged throughout the experimental period between 19.8 and $24.8^{\circ} \mathrm{C}$. After a 4 week acclimatization period, during which all the fish were fed an extruded commercial diet (Aqualife 17, Biomar S.A., France) formulated with $\mathrm{FO}$, fish from three of the tanks were changed to an $\mathrm{EO}$ diet, a pelletized experimental diet containing 50\% FO and 50\% EO, manufactured by the Institute of Aquaculture, Stirling University (Scotland, U.K.). The EO was purchased from Goerlich Pharma (Spain) and produced by cold pressing of seeds from both Echium plantagineum and Echium vulgare. Proximate compositions, lipid class and fatty acid profiles of the diets, and the fatty acid profile of EO are shown in Table 1.

Fish were fed twice a day to apparent satiation at around $2 \%$ of their biomass. Mortality was registered daily. Every four weeks the fish were individually measured for weight and length after being anesthetized with $1 \mathrm{ml}$ of chlorobutanol in ethanol (300g chlorobutanol:11 ethanol $\left.96^{\circ}\right)$ per litre seawater.

\subsection{Sampling}

After 4 months of feeding, 12 fish per dietary treatment, were randomly collected and anesthetized and blood obtained from the caudal vessel with heparinized syringes. The fish were then immediately killed by a blow to the head and liver $(n=4)$ and muscle $(n=12)$ 
samples taken, frozen in liquid nitrogen and stored at $-80{ }^{\circ} \mathrm{C}$ prior to lipid and fatty acid analyses. The remaining 8 liver samples were immediately subjected to digestion with collagenase and part of other metabolism assays to be published. The livers were previously weighed and the hepatosomatic index established using the following formula: HSI = liver weight*100/body weight. Half of the EO fish were then transferred to other tanks and returned to the FO diet and the experiment continued with the three dietary treatments for a further 3 months. This new treatment group was called EF (EO-FO). At the end of the experimental period ( 7 months in total), more individuals from each dietary treatment group were anesthetized and subsequently killed to collect the same samples described for 4 months. Fish total weight and length were also registered. The entire experiment was conducted in accordance with Spanish law 223/1988 (B.O.E. 18th March) for protection of experimental animals, in agreement with European law 89/609/CE.

\subsection{Plasma parameters}

After extraction, blood was centrifuged for $5 \mathrm{~min}$ at $3500 \mathrm{rpm}$ and $4^{\circ} \mathrm{C}$ in a microcentrifuge and the plasma $(n=6)$ collected for biochemical analysis by using standard veterinarian clinic assay kits. The parameters analyzed were: Cholesterol (mmol $\left.1^{-1}\right)$, BioSystems (cholesterol oxidase/peroxidase); Triglycerides $\left(\mathrm{mmol} \mathrm{l}^{-1}\right)$, BioSystems (glycerol phosphate oxidase/peroxidase); Glutamic Oxaloacetic Transaminase-Aspartate Transaminase, GOT-AST $\left(\mathrm{U}^{-1} 37^{\circ} \mathrm{C}\right)$, BioSystems (kinetic IFCC); Glutamic Pyruvic Transaminase-Alanine Aminotransferase, GPT-ALT (U $\left.1^{-1} 37^{\circ} \mathrm{C}\right)$, BioSystems (kinetic IFCC); Alkaline phosphatase, ALP ( $\left.\mathrm{U}^{-1} 37^{\circ} \mathrm{C}\right)$, BioSystems (diethanolamine buffer); Cholinesterase ( $\mathrm{U}^{-1} 37^{\circ} \mathrm{C}$ ), BioSystems (butiryltiocholine); Lipase $\left(\mathrm{U}^{-1} 37^{\circ} \mathrm{C}\right)$, Germon (colorimetric/metilresorufin); Proteins (g $1^{-1}$ ), BioSystems (Biuret); Glucose (mmol $1^{-1}$ ), BioSystems (glucose 
oxidase/peroxidase); Amylase ( $\left.\mathrm{U}^{-1} 37^{\circ} \mathrm{C}\right)$, BioSystems (kinetic IFCC alpha amylase-EPS) and Cortisol (ng ml$\left.{ }^{-1}\right)$, bioMerieux (E.L.F.A.).

\subsection{Analytical methods}

Moisture was determined by thermal drying of samples in an oven at $110^{\circ} \mathrm{C}$ until constant weight, according to the Official Method of Analysis of the Association of Official Analytical Chemists (A.O.A.C., 1990). Crude protein of diets was obtained by combustion using the Kjeldhal method (A.O.A.C., 1990). Ash content (percentage of dry weight) of the diets was determined by dry ashing in porcelain crucibles in a muffle furnace at $450^{\circ} \mathrm{C}$ overnight, with a previous progressive increment of temperature from 200 to $450^{\circ} \mathrm{C}$ in three hours according to A.O.A.C. (1990).

Total lipids were extracted from liver, flesh and diets by homogenization in chloroform/methanol $(2: 1, \mathrm{v} / \mathrm{v})$ containing $0.01 \%$ butylated hydroxytoluene (BHT) as antioxidant. The organic solvent was evaporated under a stream of nitrogen and the lipid content determined gravimetrically (Christie, 1982). The lipid extract was stored in chloroform/methanol (2:1) with BHT as antioxidant, under a $\mathrm{N}_{2}$ atmosphere at $-20^{\circ} \mathrm{C}$. Diets were hydrated overnight with $0.5 \mathrm{ml}$ of distilled water per 100 to $200 \mathrm{mg}$ sample, prior to their lipid extraction.

Lipid class composition was determined by high performance thin-layer chromatography (HPTLC). Approximately $30 \mu \mathrm{g}$ of lipid was applied as a $2 \mathrm{~mm}$ streak and the plate developed to one-half distance with methyl acetate/isopropanol/chloroform/ methanol/ $0.25 \%$ aqueous $\mathrm{KCl}(5: 5: 5: 2: 1.8$, by vol.), to separate polar lipid classes, and then fully developed with isohexane/diethyl ether/acetic acid (22.5:2.5:0.25, by vol.), for the neutral lipid separation. Lipid classes were visualized by charring at $160{ }^{\circ} \mathrm{C}$ for $15 \mathrm{~min}$ after spraying with $3 \%(\mathrm{w} / \mathrm{v})$ aqueous cupric acetate containing $8 \%(\mathrm{v} / \mathrm{v})$ phosphoric acid, and 
quantified by densitometry using a Dual-wavelength flying spot scanner CS-9001PC (Olsen and Henderson, 1989). The identities of individual lipid classes were confirmed by comparison with standards and to a well characterized cod roe sample.

To determine the fatty acid profiles, total lipids were subjected to acid-catalyzed transmethylation for $16 \mathrm{~h}$ at $50{ }^{\circ} \mathrm{C}$, using $1 \mathrm{ml}$ of toluene and $2 \mathrm{ml}$ of $1 \%$ sulfuric acid $(\mathrm{v} / \mathrm{v})$ in methanol. The resultant fatty acid methyl esters (FAME) were purified by thin layer chromatography (TLC), and visualized under spraying with $1 \%$ iodine in chloroform (Christie, 1982). FAME were separated and quantified using a Shimadzu GC-14A gas chromatograph equipped with a flame ionization detector $\left(250^{\circ} \mathrm{C}\right)$ and a fused silica capillary column, Supelcowax TM 10 (30 m x $0.32 \mathrm{~mm}$ I.D.). Helium was used as carrier gas and samples were applied by on-column injection at an initial temperature of $50^{\circ} \mathrm{C}$. Oven temperature was programmed to rise from 60 to $150{ }^{\circ} \mathrm{C}$ at a rate of $39{ }^{\circ} \mathrm{C} \mathrm{min}^{-1}$, and then to a final temperature of $225^{\circ} \mathrm{C}$ at $2.5^{\circ} \mathrm{C} \mathrm{min}{ }^{-1}$, which was maintained for 14 min. Individual FAME were identified by reference to authentic standards (PUFA n 3 )and to a wellcharacterized fish oil. Prior to transmethylation, heneicosanoic acid (21:0) was added to the lipid fractions as an internal standard. The results were expressed as milligrams per gram of tissue dry weight ( $\left.\mathrm{mg} \mathrm{g}^{-1} \mathrm{DWB}\right)$ for total fatty acid contents and as weight percentage of total lipid for individual fatty acids.

\subsection{Chemical and reagents}

BHT, potassium chloride, potassium bicarbonate were supplied by Sigma (St. Louis, MO). TLC (20 x $20 \mathrm{~cm}, \varnothing 0.25 \mathrm{~mm})$ and HPTLC $(10 \times 10 \mathrm{~cm}, \varnothing 0.15 \mathrm{~mm})$ plates, precoated with silica gel (without fluorescent indicator) were purchased from Machery-Nagel (Düren, Germany). Fish oil standard (PUFA N³) was supplied by SUPELCO (Supelco PARK, 
Bellefonte, USA). All organic solvents used were of reagent grade and were purchased from Panreac (Barcelona, Spain).

\subsection{Statistical analysis}

Results are presented as means \pm S.D. The data were checked for nomal distribution by the one-sample Kolmogorov-Smirnoff test, as well as, for homogeneity of the variances with the Levene test and, when necessary, arcsine transformation was applied. Effect of treatment was carried out using the Student t-test (2 variables) or one-way ANOVA (3 variables) followed by a post-hoc Tukey's multiple comparison test. When homogeneity of the variances was not achieved, data were subjected to the Kruskall-Wallis non-parametric test, followed by the non-parametric multiple comparison test Games-Howell. In all statistical tests used, P $<0.05$ was considered statistically different. The statistical analysis was performed by using the SPSS package (versions 12.0 and 14.0).

\section{Results}

\section{Diet composition}

As shown in Table 1, the proximate compositions of the two experimental diets was very similar with protein ranging from 41.6 to $43.4 \%$ and total lipid values close to $21 \%$ (DWB). As expected, diets differed in most fatty acid groups. Total saturated fatty acids of the FO diet were higher than that of the EO diet, mainly due to 16:0. Except for 16:1, individual monounsaturated fatty acids were higher in the EO diet, which also supplied an amount of n-6 fatty acids three fold higher than that of the FO diet. In this sense, 18:2n-6 and 18:3n-6 were particularly abundant in the EO diet. Total n-3 fatty acids were similar in the two diets, but EPA and DHA were 2-3 fold lower in the EO diet compared to the FO diet whereas 18:4n-3 and, especially, 18:3n-3, were greatly increased (Table 1). 


\section{Fish food intake, growth and survival}

Fish food intake was of around $2 \%$ of their biomass per day and quite similar for all diets. No significant differences were observed in fish final total weight or length among dietary treatments, with values of $447.5 \pm 74.5 \mathrm{~g}$ and $27.8 \pm 1.8 \mathrm{~cm}$ for FO-fed fish, $432.7 \pm 54.2$ $\mathrm{g}$ and $27.6 \pm 1.2 \mathrm{~cm}$ for EO-fed fish and $453.4 \pm 38.5 \mathrm{~g}$ and $27.65 \pm 0.53 \mathrm{~cm}$ for EF diet (Fig. 2). Mortality over the experimental period was less than $1 \%$ for all treatments.

\section{Plasma parameters}

Some plasma parameters, including the activities of the GPT, ALP and cholinesterase enzymes, were reduced in seabream fed the EO diet compared to fish fed the FO diet after 4 months of feeding, although these differences were no longer observed after 7 months of feeding (Table 2).

\section{HSI and lipid profiles}

After 4 months of feeding, the hepatosomatic index (HSI) of fish fed the EO diet, was slightly lower than that of fish fed the FO diet. However, these differences were not statistically significant due to the high variability in the data. Nevertheless, after 7 months of feeding, the HSI from EO-fed fish was significantly lower than that of the FO-fed fish, whereas in EF (washout) fish the HSI was restored to the value in the FO fish (Table 4).

Total lipid levels of muscle significantly decreased over the course of feeding for fish fed the EO diet. In liver lipids also appeared to decrease although the differences were not statistically significant (Tables 3 and 4). After feeding EO for 4 months muscle lipid class composition was already significantly affected with a fall of total neutral lipid. After 7 months, total neutral lipids, primarily triacylglycerols were also reduced in fish fed the EO diet compared to fish fed the FO diet (Table 3). With the washout period this differences 
tended to reduce but not completely and they continued being different from the FO group. Liver lipids showed a similar trend to that in muscle with trend triacylglycerols decreasing, and phospholipids, particularly phosphatidylcholine, increasing over the course of the feeding trial in fish fed the EO diet compared to fish fed the FO diet, although these effects were not significant due to the high variability in the data (Table 4).

After 4 months, muscle and liver fatty acid profiles clearly reflected those of the diets (Table 5). Fish fed the EO diet showed significantly increased proportions of 18:2n-6, 18:3n-6 and 20:3n-6 and, as a result, total n-6 fatty acids also increased. Furthermore, n-3 HUFA specifically EPA, and n-3/n-6 ratio were reduced in tissue lipids in fish fed the EO diet.

Fatty acid compositions of muscle and liver at the end of the trial ( 7 months) are shown in Tables 6 and 7 respectively. In both muscle and liver, saturated (mainly 16:0) and monounsaturated fatty acids decreased in fish fed the EO diet compared to fish fed the FO diet, while the n-6 fatty acids showed the opposite trend, specially de $C_{18}$ fatty acids. Total n3 fatty acids significantly increased in liver, and slightly in muscle, of fish fed the EO diet compared with fish fed the FO diet, but this was due to the $\mathrm{C}_{18}$ fatty acids that were significantly higher. No significant differences were found in total n-3 HUFA in muscle, with the DHA level apparently being unaffected although EPA and 22:5n-3 were significantly reduced. In liver the DHA only slighty decreased but n-3 HUFA, EPA and 22:5n-3 were significantly reduced. Specifically comparing the DHA values in muscle from fish fed FO and EO for 4 and 7 months, an interesting difference can be observed (17.5\% and $15.1 \%$ in FO and EO, respectively, at 4 months vs $13.2 \%$ and $13.1 \%$ at 7 months). Clearly, DHA decreases in muscle between 4 and 7 months even in fish fed FO, presumably related to the increase in flesh fat content although why DHA should decrease in relative terms is unclear. However, taking into account the higher fat content in older fish, combined with the fact that the lower fat content in EO fish compared to FO fish is also more pronounced at 7 months, the level of 
DHA expressed in absolute terms was significantly lower $(\mathrm{p}<0.05)$ in EO fish $(4.98 \pm 0.91 \mathrm{mg}$

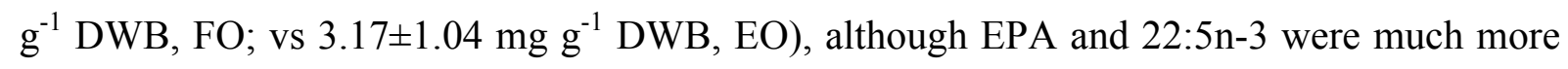
susceptible to decrease than DHA $(\mathrm{p}<0.01)$. As a result of EPA reduction, the DHA/EPA ratio was significantly higher in fish fed the EO diet compared to fish fed the FO diet. Similarly, as n-6 fatty acids were increased 2-fold in fish fed the EO diet compared to fish fed the FO diet, the n-3/n-6 ratio decreased by $50 \%$ and the AA/EPA ratio increased in fish fed EO. Importantly, 20:3n-3 and 20:3n-6 appeared in the tissues of fish fed the EO diet despite these fatty acids being absent from the EO diet (Table 1). Furthermore these increments were always significant except for 20:3n-3 in muscle of fish fed for 4 month. After the washout period (EF group), the fatty acid composition of muscle was partially restored to the values observed with the FO group (Table 6). Specifically, over $75 \%$ of the effect of EO feeding was abolished with 18:3n-6 and 18:3n-3, whereas for $16: 1,18: 2 n-6$ and 20:5n-3 the effects of EO feeding were only diminished by around 50\% (Table 6). The washout period had a greater effect in liver, and only 16:1 and 18:3n-6 showed significant differences between the FO and EF fish (Table 7).

\section{Discussion}

Aquaculture is investigating new oil sources for fish diets because FO supplies are becoming more and more limiting (New, 1999). Researchers are focussing on various VOs such as rapeseed (Bell et al., 2001), soybean and linseed (Izquierdo et al., 2005), as well as some borraginaceae plants (Bell et al., 2006; Tocher et al., 2006), with some good results obtained with both salmonids (Bell et al., 2001, 2003, Caballero et al., 2002) and marine fish (Montero et al., 2003, 2005; Benedito-Palos et al., 2007). Generally, these studies have shown that growth and other developmental parameters were largely unchanged with $100 \%$ substitution of FO in salmonids (Bell et al., 2003; Tocher et al., 2006), or up to $60 \%$ 
substitution in marine fish species (Montero et al., 2003; Izquierdo et al., 2005). The lower level of replacement possible with marine fish is explained by their requirement for higher levels of dietary EPA and DHA for optimal growth and health (Kalogeropoulos et al., 1992; Ibeas et al., 1994), due to their inability to produce sufficient HUFA endogenously associated with restricted capacity of the enzymes necessary to elongate and desaturate the precursor 18:3n-3 (LNA) (Tocher et al., 2003; Mourente et al., 2005).

In our study, gilthead seabream survival and growth were not affected by $50 \%$ substitution of FO by EO in the diet in agreement with other studies carried out in the same species using up to $60 \%$ substitution with linseed and soybean oils (Izquierdo et al., 2005). In contrast, growth of seabream was reduced with $80 \%$ substitution of FO with VO (Menoyo et al., 2004; Izquierdo et al., 2005, Benedito-Palos et al., 2007). Although fish may prefer FO to VO and extruded to pelletized diets (Geurden et al., 2005, 2007), in our case, both diets, the pelletized 50\% EO diet and the extruded FO diet were consumed equally through the experimental period.

After seven months of feeding, plasma parameters, measured as indicators of overall health status of the fish, did not vary greatly between the fish fed FO or EO. Many plasma parameters will vary during the day and with time of feeding (Polakof et al., 2007), but they were measured in samples collected at exactly the same time in all groups. Triglyceride, glucose and cholesterol values were similar to those reported in other studies with gilthead seabream and tilapia (Laiz-Carrión et al., 2002, 2005; Chen et al., 2003), and protein values were also consistent with those previously reported in gilthead seabream, sturgeon and tilapia (Montero et al., 1998; Martinez-Álvarez et al., 2002; Chen et al., 2003). Previously, Lee et al., (2003), showed that plasma protein, glucose and cholesterol levels were not affected by dietary VO in starry flounder, but GOT decreased with $60-80 \%$ substitution of FO with VO, whereas with total or low substitution levels this hepatic enzyme reached higher values (Lee 
et al., 2003). Several hepatic enzymes such as GOT, ALP and cholinesterase decreased after 4 months of feeding with EO in the present trial. Increased hepatic enzymes may indicate hepatic lesion, perhaps a result of induced stress as reported in tilapia (Chen et al., 2003). In contrast, few studies report reduction activity of these enzymes, although Chen et al., (2003) showed GTP, GOT and ALP decreased with nephrocalcinosis in tilapia. However, the values for these enzymes vary greatly among studies and species (Lee et al., 2003; Chen et al., 2003) and through the year in healthy fish (Chen et al., 2003). Therefore, it is difficult to establish a healthy range for these parameters in fish, and to conclude whether the values in fish fed EO for 4 months remained within a healthy range despite being significantly different to those from the fish fed FO. In the absence of any other supporting data, we conclude that the lower hepatic enzymes levels found in EO fish did not reflect major pathology particularly as the activities had returned to the level of those in fish fed FO after 7 months of feeding. Cortisol values were unaffected by diet after 4 months and were similar to other studies with confined gilthead seabream (Montero et al., 1998; Laiz-Carrión et al., 2002). At the end of the trial the cortisol range was higher, probably due to water temperature, which increased from 20 to $25^{\circ} \mathrm{C}$ over the experimental period. Cortisol was shown to increase with increasing water temperature in Adriatic sturgeon, (Cataldi et al., 1998).

The inclusion of VOs in diets for carnivorous fish may produce an increment in liver fat (Kalogeropoulos et al., 1992; Menoyo et al., 2004), HSI (Piedecausa et al., 2007) and lipid droplets in both hepatocytes and enterocytes (Olsen et al., 1999; Caballero et al., 2002). In contrast to other studies with VO (Figueiredo-Silva et al., 2005; Benedito-Palos et al., 2007), the HSI as well as the lipid contents in the muscle were lower and it tended to be lower in liver in fish fed the EO diet compared with those fed the FO diet. This effect was confirmed by the finishing period where HSI in the EF fish were restored to the values of fish fed the FO diet. Nevertheless, in this period the total lipids in the tissues tended to be only partly 
restored. A similar effect of VO on HSI in seabream has been reported previously (Menoyo et al. 2004; Benedito-Palos et al., 2007), although liver fat level was contradictorily increased in one of the studies (Menoyo et al. 2004). In the present study HSI values were lower, even in fish fed the FO diet, than those reported by Menoyo et al. (2004) and Benedito-Palos et al., (2007). Lower HSI is also found in wild gilthead seabream (Grigorakis et al., 2002) and may be an indicator of healthier fish. The fact that tissue fat was decreased by the dietary EO may be partly explained by the lower level of $18: 2 \mathrm{n}-6$, which has been, according to the abundant available bibliography, implicated in the fat accumulation observed in fish fed other VOs (Sargent et al., 2002). On the other hand, other research showed that $\gamma$-linolenic acid (18:3n-6) reduced weight gain and body fat in rats (Phinney et al., 1993) and facilitated fatty acyl $\beta$ oxidation in rat liver (Takada et al., 1994).

The significant fat reduction in muscle and the similar trend observed in liver was supported by the lipid class data that showed the proportions of total neutral lipids and mainly triacyglycerides tended to decrease in fish fed EO compared to fish fed FO. In other studies performed with different VO including EO the authors do not report lipid class profiles (Figueiredo-Silva et al., 2005; Bell et al., 2006).

Fatty acid profiles in muscle and liver reflected the dietary VO profiles as observed in similar studies performed with different fish species (Montero et al., 2005; Bell et al., 2006). Thus, and in agreement with other trials (Bell et al., 2006; Tocher et. al, 2006), EPA was significantly reduced and $\mathrm{C}_{18}$ fatty acids increased in fish fed EO. In studies with all VOs, 18:2n-6 and 18:3n-3 are increased (Bell et al., 2003; Izquierdo et al., 2005), but with EO the $\mathrm{C}_{18}$ fatty acids, including 18:3n-6 and 18:4n-3, increased as in the present trial (Bell et al., 2006; Tocher et. al, 2006). In previous studies with EO, DHA and ARA were also clearly decreased in both Arctic char and Atlantic cod (Bell et al., 2006; Tocher et. al, 2006). Surprisingly, ARA and DHA were not apparently reduced in the present study with gilthead 
seabream. However, when expressed in absolute terms ( $\mathrm{mg} \mathrm{g}^{-1}$ DWB) DHA and ARA values were significantly lower in EO fish muscle after 7 months of feeding (4.98 and 3.17 in FO and EO fish respectively and 0.23 and 0.16 for ARA in FO and EO respectively).

Dietary VO induced HUFA synthesis activity in freshwater fish (Tocher et al., 1997; Bell et al., 2001). Furthermore, desaturation of 18:3n-3 was greater in fish fed EO than fish fed FO in cod (Bell et al., 2006). Elongation activity was observed in the present study, as 20:3n-6 and 20:3n-3 increased in the tissues of fish fed EO despite not being supplied by the diet, suggesting elongation of their respective dietary precursors, $18: 3 n-6$ and 18:3n-3. Although, $\mathrm{C}_{18-20}$ elongation activity is low in some fish species (Ghioni et al., 1999), the $\mathrm{C}_{20}$ elongation products accumulated in fish fed EO support the fact that desaturase activity is very low in marine fish including seabream (Tocher and Ghioni, 1999; Bell et al., 2006). However, 18:4n-3 from EO was not elongated to $20: 4 n-3$ in gilthead seabream, the same situation as observed in cod where 20:4n-3 actually decreased (Tocher et al., 2006). The lack of any accumulation of $20: 4 n-3$ was not due to it being a metabolic intermediate in HUFA production as n-3HUFA were not increased, with EPA clearly decreased and, although DHA tended to be maintained, this was probably due to the known phenomenon of high retention rather than synthesis.

After the wash out period, tissue fatty acid compositions were partly restored as also shown in other studies. In salmon previously fed VO, EPA and DHA levels were restored to around $80 \%$ and $18: 2 \mathrm{n}-6$ to about $50 \%$ of values in fish fed FO (Bell et al., 2003). In sea bass fed VO with a FO wash out period of 150 days, DHA was completely restored but EPA remained lower and 18:2n-6 and 18:3n-3 higher (Montero et al., 2005). Similarly, in our study not all fatty acids returned to the levels in fish fed FO, including 18:2n-6, 18:3n-3 and EPA in the muscle. EPA was also more difficult than DHA to be restored in a previous study with gilthead seabream where $60 \%$ substitution of FO by VOs followed by a washout was 
investigated (Izquierdo et al., 2005). In addition, the beneficial fatty acids, 18:3n-6 and 18:4n3, which may be responsible for reducion in tissues fat levels, were mostly removed. Therefore, a washout phase may not be beneficial in seabream fed EO as a FO substitute, as 18:2n-6 was not totally reduced and EPA not fully recovered, and the potential beneficial effects of a fatty acid profile richer in 18:3n-6, 18.4n-3 and 20:3n-6 were removed.

In summary, $50 \%$ substitution of FO by EO in gilthead seabream did not negatively affect growth and health of fish. Moreover, the EO reduced fat in muscle and the resultant fatty acid profile of fish flesh is relatively good compared to other VO substitutes, and may not require a washout period with a FO finishing diet.

\section{Acknowledgements}

This study was supported by grant AGL 2003-06877 from the Spanish Ministerio de Educación y Ciencia, plan I+D+I 2003. Dr. Covadonga Rodríguez was supported by a research position of the Ramón y Cajal Programme from Ministerio de Ciencia y Tecnología (MCYT) and FSE (RYC 2001-2824) Spain, and Mercedes Díaz López was supported by a grant from Caja Canarias. Drs. Covadonga Rodríguez and Antonio Lorenzo are members from the IUTB of La Laguna University (Spain).

\section{Bibliography}

Ackman, R.G. (1980). Fish lipids. In: Advances in Fish Sciences and Technology (Connell, J.J. ed.), 1st part, pp. 86-103. Fishing News Books, Farnham, U.K.

Association of Official Agricultural Chemists (AOAC) 1990. Official Methods of Analysis. 15th Ed. AOAC, Arlington, VA. 
Balfry, S.K. and Higgs, D.A. (2001). Influence of dietary lipid composition on the immune system and disease resistance of finfish. In: Nutrition and Fish Health (Lim, C. and C.D. Webster eds.), pp. 213-234. Haworth Press In., New York, USA.

Bell, J.G., Tocher, D.R., MacDonald, F.M. and Sargent, J.R. (1994). Effects of diets rich in linoleic (18:2n-6) and $\alpha$-linolenic (18:3n-3) acids on the growth, lipid class and fatty acid compositions and eicosanoid production in juvenile turbot (Scophthalmus maximus L.). Fish Physiol. Biochem., 13, 105-118.

Bell, J.G., Tocher, D.R., Farndale, B.M., Cox, D.I., McKinney, R.W. and Sargent, J.R. (1997). The effect of dietary lipid on polyunsaturated fatty acid metabolism in Atlantic salmon (Salmo salar) undergoing parr-smolt transformation. Lipids, 32, 515-525.

Bell, J.G., McEvoy, J., Tocher, D.R., McGhee, F., Campbell, P.J. and Sargent, J.R. (2001). Replacement of fish oil with rapeseed oil in diets of Atlantic salmon (Salmo salar) affects tissue lipid compositions and hepatocyte fatty acid metabolism. J. Nutr., 131, 1535-1543.

Bell, J.G., McGhee, F., Campbell, P.J. and Sargent, J.R. (2003). Rapeseed oil as an alternative to marine fish oil in diets of post-smolt Atlantic salmon (Salmo salar): changes in flesh fatty acid composition and effectiveness of subsequent fish oil "wash out". Aquaculture, $218,515-528$.

Bell, J.G., McGhee, F., Dick, J.R. and Tocher, D.R. (2005). Dioxin and dioxin-like polychlorinated biphenyls (PCBs) in Scottish farmed salmon (Salmo salar): effects of replacement of dietary marine fish oil with vegetable oils. Aquaculture, 243, 305-314.

Bell, J.G., Strachan, F., Good, J.E. and Tocher, D.R. (2006). Effect of dietary echium oil on growth, fatty acid composition and metabolism, gill prostaglandin production and macrophage activity in Atlantic cod (Gadus morhua L.). Aquac. Res. 37 (6), 606-617.

Benedito-Palos, L., Saera-Villa, A., Calduch-Giner, J-A., Kaushik, S. and Pérez-Sánchez, J. (2007). Combined replacement of fish meal and oil in practical diets for fast growing 
juveniles of gilthead sea bream (Sparus aurata L.): Networking of systemic and local components of GH/IGF axis. Aquaculture, 267, 199-212.

Bimbo, A.P. (1990). Production of fish oil. In: Fish Oils Nutrition (Stansby M.E. ed.), Chap. 6, pp. 141-180, Van Nostrand Reinhold, New York, USA.

Caballero, M.J., Obach, A., Rosenlund, G., Montero, D., Gisvold, M. and Izquierdo, M.S. (2002). Impact of different dietary lipid sources on growth, lipid digestibility, tissue fatty acid composition and histology of rainbow trout (Oncorhynchus mykiss). Aquaculture, 214, 253-271.

Cataldi, E., Di Marco, P., Mandich, A. and Cataudella, S. (1998). Serum parameters of Adriatic sturgeon Acipenser naccarii (Pises: Acipenseriformes): effects of temperature and stress. Comp. Biochem. Physiol., A, 121, 351-354.

Chen, C-H., Wooster, G.A., Getchell, R.G., Bowser, P.R. and Timmons, M.B. (2003). Blood chemistry of healthy, nephrocalcinosis-affected and ozone-treated tilapia in a recirculation system, with application of discriminant analysis. Aquaculture, 218, 89-102.

Christie, W.W. (1982). Lipid Analysis. In: Lipid Analysis (Christie, W.W. ed.), pp 17-23, 51-61. Pergamon Press, Oxford.

Drew, M.D., Ogunkoya A.E., Janz D.M. and Van Kessel A.G. (2007). Dietary influence of replacing fish meal and oil with canola protein concentrate and vegetable oils on growth performance, fatty acid composition and organochlorine residues in rainbow trout (Oncorhynchus mykiss). Aquaculture 267, 260-268.

FAO, 2004. El estado mundial de la pesca y la acuicultura.

Figueiredo-Silva, A., Rocha, E., Días, J., Rema, P., Gomes, E. and Valente, L.M.P. (2005). Partial replacement of fish oil by soybean oil on lipid distribution and liver histology in European sea bass (Dicentrarchus labrax) and rainbow trout (Oncorhynchus mykiss) juveniles. Aquac. Nutr., 11, 147-155. 
Geurden, I., Cuvier, A., Gondouin, E., Olsen, R.E., Rouhonen, K., Kaushik, S. and Boujard, T. (2005). Rainbow trout can discriminate between feeds with different oil sources. Physiol. Behav., 85, 107-114.

Geurden, I., Corraze, G. and Boujard, T. (2007). Self-feeding behavior of rainbow trout, Oncorhynchus mykiss, offered diets with distinct feed oils. Appl. Anim. Behav. Sci., 108, 313-326.

Ghioni, C., Tocher, D.R., Bell, M.V., Dick, J.R. and Sargent, J.R. (1999). Fatty acid elongase activity and limited conversion of stearidonic acid, 18:4n-3, to eicosapentaenoic acid, 20:5n-3, in a cell line from turbot, Scophthalmus maximus. Biochem. Biophys. Acta, $1437,170-181$.

Ghioni, C., Porter, E.A.E., Taylor, G.W. and Tocher, D.R. (2002). Metabolism of 18:4n-3 (stearidonic acid) and 20:4n-3 in salmonid cells in culture and inhibition of the production of prostaglandin F2a (PGF2a) from 20:4n-6 (arachidonic acid). Fish Physiol. Biochem., 27, 81-96.

Grigorakis, K., Alexis, M.N., Taylor, K.D.A. and Hole. M. (2002). Comparison of wild and cultured gilthead sea bream (Sparus aurata); composition, appearance and seasonal variations. Int. J. Food Sci. Tech., 37, 477-484.

Guil Guerrero, J.L., Rebolloso Fuentes, M.M., Campra Madrid, P., García-Maroto, F. and Torija Isasa, M.E. (2000a). "Occurrence and Characterization of Oils Rich in gamma-linolenic acid (I): Echium from Macaronesia ". Phytochemistry, 53, 451-456.

Guil-Guerrero, JL, García-Maroto, F., Campra-Madrid, P. and Gómez Mercado F. (2000b). "Occurrence and Characterization of Oils Rich in gamma-linolenic acid (II): fatty acids and squalene from Macaronesian Echium leaves". Phytochemistry, 56, 525-529. 
Horia, E. and Watkins, B.A. (2005). Comparison of stearidonic acid and $\alpha$-linolenic acid on PGE2 production and COX-2 protein levels in MDA-MB-231 breast cancer cell cultures. J. Nutr. Biochem., 16, 184-192.

Ibeas, C., Izquierdo, M.S. and Lorenzo, A. (1994). Effect of different levels of n-3 highly unsaturated fatty acids on growth and fatty acid composition of juvenile gilthead seabream (Sparus aurata). Aquaculture, 127, 177-188.

Izquierdo, M.S., Montero, D., Robaina, L., Caballero, M.J., Rosenlund, G. and Ginés R. (2005). Alterations in fillet fatty acid profile and flesh quality in gilthead seabream (Sparus aurata) fed vegetable oils for a long term period. Recovery of fatty acid profiles by fish oil feeding. Aquaculture, 250, 431-444.

Kalogeropoulos, N., Alexis, M.N. and Henderson, R.J. (1992). Effect of dietary soybean and cod-liver oil levels on growth and body composition of gilthead bream (Sparus aurata). Aquaculture, 104, 293-308.

Laiz-Carrión, R., Sangiao-Alvarellos, S., Guzmán J.M., Martín del Río, M.P., Míguez, J.M., Soengas, J.L. and Mancera, J.M. (2002). Energy metabolism in fish tissues related to osmoregulation and cortisol action. Fish Physiol. Biochem., 27, 179-188.

Laiz-Carrión, R., Sangiao-Alvarellos, S., Guzmán J.M., Martín del Río, M.P., Soengas, J.L. and Mancera, J.M. (2005). Growth performance of gilthead sea bream Sparus aurata in different osmotic conditions: Implications for osmoregulation and energy metabolism. Aquaculture, 250, 849-861.

Lee, S-M., Lee, J.H. and Kim, K-D. (2003). Effect of dietary essential fatty acids on growth, body composition and blood chemistry of juvenile starry flounder (Platichthys stellatus). Aquaculture, 225, 269-281. 
Martínez-Álvarez, R.M., Hidalgo, M.C., Domezain, A., Morales, A.E., García-Gallego, M. and Sanz, A. (2002). Physiological changes of sturgeon Acipenser naccarii caused by increasing environmental salinity. J. Exp. Biol., 205, 3699-3706.

Menoyo, D., Izquierdo, M.S., Robaina, L., Gines, R., López-Bote, C.J. and Bautista, J.M. (2004). Adaptation of lipid metabolism, tissue composition and flesh quality in gilthead sea bream (Sparus aurata) to the replacement of dietary fish oil by linseed and soyabean oils. Br. J. Nutr., 92, 41-52.

Montero, D., Tort, L., Izquierdo, M.S., Robaina, L. and Vergara, J. M. (1998). Depletion of serum alternative complemented pathway activity in gilthead seabream (Sparus auratus) caused by $\alpha$-tocopherol and n-3 HUFA dietary deficiencies. Fish Physiol. Biochem., 18, $399-407$.

Montero, D., Kalinowski, T., Obach, A., Robaina, L., Tort, L., Caballero, M.J. and Izquierdo, M.S. (2003). Vegetable lipid sources for gilthead seabream (Sparus aurata): effects on fish health. Aquaculture, 225, 353-370.

Montero, D., Robaina, L., Caballero, M.J., Ginés, R. and Izquierdo, M.S. (2005). Growth, feed utilization and flesh quality of European sea bass (Dicentrarchus labrax) fed diets containing vegetable oils: A time-course study on the effect of a re-feeding period with a $100 \%$ fish oil diet. Aquaculture, 248, 121-134.

Mourente, G., Dick, J.R., Bell, J.G. and Tocher, D.R. (2005). Effect of partial substitution of dietary fish oil by vegetable oils on desaturation and $\beta$-oxidation of [1-14C] 18:3n-3 (LNA) and [1-14C] 20:5n-3 (EPA) in hepatocytes and enterocytes of European seabass (Dicentrarchus labrax L.). Aquaculture, 248, 173-186.

New, M. B. (1999). Global Aquaculture: current trends and challenges for the $21^{\text {st }}$ century. World Aquaculture, 30, 8-13. 
Okuyama, H., Kobayashi, T. and Watanabe, S. (1997). Dietary fatty acids-The n-6/n-3 balance and chronic elderly diseases. Excess linoleic acid and relative n-3 deficiency syndrome seen in Japan. Prog. Lipid Res., 3, 409-457.

Olsen, R.E. and Henderson, R.J. (1989). The rapid analysis of neutral and polar marine lipids using double-development HPTLC and scanning densitometry. J. Exp. Mar. Biol. Ecol., $129,189-197$.

Olsen, R.E., Myklebust, R., Kaino, T. and Ringo, E., (1999). Lipid digestibility and ultrastructural changes in the enterocytes of Arctic char (Salvelinus alpinus L.) fed linseed oil and soybean lecithin. Fish Physiol. Biochem., 21, 35-44.

Piedecausa, M.A., Mazón, M.J., García García B. and Hernández M.D. (2007). Effects of total replacement of fish oil by vegetable oils in the diets of sharpsnout seabream (Diplodus puntazzo). Aquaculture, 263, 211-219.

Phinney, S.D., Tang, A.B., Thurmond, D.C., Nakamura, M.T. and Stern JS. (1993). Abnormal polyunsaturated lipid metabolism in the obese Zucker rat, with partial metabolic correction by $\gamma$-linolenic acid administration. Metabolism, 42, 1127-1140.

Polakof, S., Ceinos, R.M., Fernández-Durán, B., Míguez, J.M. and Soengas, J.L. (2007). Daily changes in parameters of energy metabolism in brain of rainbow trout: Dependence on feeding. Comp. Biochem. Physiol. A, 146, 265-273.

Sargent, J.R. and Tacon, A.G.J. (1999). Development of farmed fish: a nutritionally necessary alternative to meat. Proc. Nutr. Soc., 58, 377-383.

Sargent, J.R., Bell, J.G., McEvoy, L.A., Tocher, D.R. and Estevez, A. (1999). Recent developments in the essential fatty acid nutrition of fish. Aquaculture, 177, 191-199.

Sargent, J.R., Tocher, D.R. and Bell, J.G. (2002). The lipids. In: Fish Nutrition (Halver, J.E. and Hardy, R.W. eds.), third edn, pp. 181-257. Academic Press, New York. 
Sayanova, O.V. and Napier, J.A. (2004). Eicosapentaenoic acid: biosynthetic routes and the potential for synthesis in transgenic plants. Phytochemistry, 65, 147-158.

Simopoulos, A.P. (2000). Human requirements for n-3 polyunsaturated fatty acids. Poult.Sci., 79, 961-993.

Tacon, A.G.J. (2004). Use of fish meal and fish oil in aquaculture: a global perspective. Aquat. Resour. Cult. Dev., 1, 3-14.

Takada, R., Saitoh, M. and Mori, T., (1994). Dietary gamma-linolenic acid-enriched oil reduces body fat content and induces liver enzyme activities relating to fatty acid Boxidation in rats. J. Nutr., 124, 469 - 474.

Tocher, D. R. and Ghioni, C. (1999). Fatty acid metabolism in marine fish: low activity of fatty acyl $\Delta 5$ dasaturation in gilthead seabream (Sparus aurata) cells. Lipids, 34 (5), 433-439.

Tocher, D.R., Bell, J.G., Dick and J.R. and Sargent, J.R. (1997). Fatty acyl desaturation in isolated hepatocytes from Atlantic salmon (Salmo salar): Stimulation by dietary borage oil containing $\gamma$-linolenic acid. Lipids, 32 (12), 1237-1247.

Tocher, D. R., Bell, J. G., Dick, J. R. and Crampton, V. (2003). Effects of vegetable oil diets on Atlantic salmon hepatocyte desaturase activities and liver fatty acid compositions. Lipids, 38(7), 723-732.

Tocher, D.R., Dick, J.R., MacGlaughlin, P. and Bell. J.G. (2006). Effect of diet enriched in $\Delta 6$ desaturated fatty acids (18:3n-6 and 18:4n-3), on growth, fatty acid composition and highly unsaturated fatty acid synthesis in two populations of Arctic charr (Salvelinus alpinus L.). Comp. Biochem. Physiol., B, 144, 245-253.

Villalta, M., Estévez, A., Bransden, M.P. and Bell J.G. (2007). Arachidonic acid, arachidonic/eicosapentaenoic acid ratio, stearidonic acid and eicosanoids are involved in dietary-induced albinism in Senegal sole (Solea senagalensis). Aquaculture Nutrition, 13, $1-9$ 
Weber, P.C. (1990). The modification of the arachidonic acid cascade by n-3 fatty acids. In: Advances in Prostaglandin, Tromboxane and Leukotriene Research. Vol. 20. (Samuelsson, B.; Dahlen, S.-E.; Fritsch, J.and Hedqvist, P., Eds.) Raven, New York. 232240. 
Table 1. Proximate composition (\%DWB), lipid class (\%DWB) and fatty acid profiles (weight \%) of dietary treatments and Echium oil.

\begin{tabular}{|c|c|c|c|}
\hline & FO diet & EO diet & Echium oil \\
\hline $\begin{array}{l}\% \text { Moisture } \\
\% \text { Ash } \\
\% \text { Crude fiber } \\
\% \text { Protein } \\
\% \text { Fat } \\
\% \text { Neutral lipid } \\
\% \text { Polar lipid }\end{array}$ & $\begin{array}{r}9.0 \pm 1.1 \\
7.3 \pm 0.2 \\
3.0 \pm 0.0 \\
41.6 \pm 0.6 \\
20.7 \pm 1.6 \\
19.1 \pm 0.1 \\
1.6 \pm 0.1 \\
\end{array}$ & $\begin{aligned} 8.9 & \pm 0.3 \\
8.7 & \pm 0.4 \\
3.1 & \pm 0.0 \\
43.4 & \pm 0.9 \\
20.7 & \pm 0.8 \\
18.8 & \pm 0.1 \\
1.9 & \pm 0.1\end{aligned}$ & \\
\hline $16: 0$ & $18.7 \pm 0.4$ & $10.8 \pm 0.0$ & 5.5 \\
\hline $16: 1^{1}$ & $6.7 \pm 0.0$ & $3.5 \pm 0.0$ & 0.0 \\
\hline $18: 0$ & $3.6 \pm 0.2$ & $2.2 \pm 0.0$ & 2.6 \\
\hline $18: 1 \mathrm{n}-9$ & $9.8 \pm 0.3$ & $12.3 \pm 0.0$ & 14.8 \\
\hline $18: 2 n-6$ & $4.4 \pm 0.1$ & $13.4 \pm 0.0$ & 26.9 \\
\hline $18: 3$ n-6 & $0.2 \pm 0.0$ & $4.7 \pm 0.0$ & 10.5 \\
\hline $18: 3 n-3$ & $1.4 \pm 0.1$ & $14.0 \pm 0.0$ & 29.9 \\
\hline $18: 4$ n-3 & $2.8 \pm 0.1$ & $5.4 \pm 0.0$ & 8.0 \\
\hline $20: 1^{2}$ & $2.1 \pm 0.0$ & $6.5 \pm 0.0$ & 0.9 \\
\hline $20: 2 n-6$ & $0.2 \pm 0.0$ & $0.2 \pm 0.0$ & 0.1 \\
\hline $20: 3 n-6$ & $0.1 \pm 0.1$ & $0.0 \pm 0.0$ & 0.0 \\
\hline $20: 4 n-6$ & $0.8 \pm 0.0$ & $0.1 \pm 0.2$ & 0.0 \\
\hline $20: 3 n-3$ & $0.2 \pm 0.0$ & $0.3 \pm 0.1$ & 0.0 \\
\hline $20: 4 n-3$ & $0.7 \pm 0.0$ & $0.1 \pm 0.2$ & 0.0 \\
\hline $20: 5 n-3$ & $12.3 \pm 0.5$ & $4.3 \pm 0.0$ & 0.0 \\
\hline $22: 1^{2}$ & $1.8 \pm 0.2$ & $7.3 \pm 0.0$ & 0.3 \\
\hline $22: 5 n-3$ & $1.4 \pm 0.1$ & $0.4 \pm 0.0$ & 0.0 \\
\hline $22: 6 n-3$ & $13.1 \pm 0.2$ & $5.6 \pm 0.0$ & 0.0 \\
\hline UK & $1.5 \pm 0.3$ & $0.5 \pm 0.1$ & 0.1 \\
\hline Saturates & $30.5 \pm 0.3$ & $17.0 \pm 0.0$ & 8.24 \\
\hline Monoenes & $25.9 \pm 0.1$ & $32.9 \pm 0.2$ & 16.02 \\
\hline$n-9$ & $13.2 \pm 0.3$ & $19.7 \pm 0.0$ & 14.98 \\
\hline$n-6$ & $6.1 \pm 0.2$ & $18.5 \pm 0.3$ & 37.47 \\
\hline$n-3$ & $32.9 \pm 0.7$ & $30.6 \pm 0.3$ & 37.95 \\
\hline n-3 HUFA & $28.2 \pm 0.7$ & $11.0 \pm 0.3$ & 0.00 \\
\hline$n-3 / n-6$ & $5.4 \pm 0.3$ & $1.7 \pm 0.0$ & 1.01 \\
\hline 18:1/n-3 HUFA & $0.4 \pm 0.0$ & $1.3 \pm 0.0$ & 8.24 \\
\hline $\mathrm{AA} / \mathrm{EPA}$ & $0.1 \pm 0.0$ & $0.0 \pm 0.0$ & --- \\
\hline DHA/EPA & $1.1 \pm 0.0$ & $1.3 \pm 0.0$ & --- \\
\hline
\end{tabular}

Results represent means $\pm \mathrm{SD}(\mathrm{n}=3)$. Totals include some minor components not shown. DWB: Dry weight basis. UK: Unknown. ${ }^{1}$ Contains n-9 and n-7 isomers. ${ }^{2}$ Contains n-11 and n-9 isomers. 
Table 2. Plasma parameters from gilthead seabream after 4 and 7 months of feeding with the FO,

EO and EF (washout period of 3 months) diets.

\begin{tabular}{|c|c|c|c|c|c|c|}
\hline Plasma parameters (4 months) & FO diet & & \multicolumn{4}{|c|}{ EO diet } \\
\hline Cholesterol $\left(\mathrm{mmol} \mathrm{l}^{-1}\right)$ & $5.7 \pm$ & 0.5 & 6.3 & \pm & 0.6 & \\
\hline Triglycerides $\left(\mathrm{mmol} \mathrm{l}^{-1}\right)$ & $3.4 \pm$ & $\pm \quad 0.8$ & 2.9 & \pm & 1.1 & \\
\hline GOT - AST $\left(\mathrm{U}^{-1} 37^{\circ} \mathrm{C}\right)$ & $24.5 \pm$ & \pm 11.1 & 13.3 & \pm & 4.2 & \\
\hline GPT - ALT $\left(\mathrm{U}^{-1} 37^{\circ} \mathrm{C}\right)$ & $8.7 \pm$ & $\pm \quad 3.3$ & 4.0 & \pm & 0.0 & * \\
\hline $\operatorname{ALP}\left(\mathrm{U}^{-1} 37^{\circ} \mathrm{C}\right)$ & $300.0 \pm$ & \pm 57.5 & 208.0 & \pm & 62.8 & * \\
\hline Cholinesterase $\left(\mathrm{U} \mathrm{l}^{-1} 37^{\circ} \mathrm{C}\right)$ & $40.9 \pm$ & $\pm \quad 5.5$ & 34.0 & \pm & 4.2 & * \\
\hline Lipase $\left(\mathrm{U}^{-1} 37^{\circ} \mathrm{C}\right)$ & $61.4 \pm$ & \pm 19.3 & 55.6 & \pm & 16.7 & \\
\hline Protein $\left(\mathrm{g} \mathrm{l}^{-1}\right)$ & $39.6 \pm$ & $\pm \quad 3.3$ & 34.8 & \pm & 6.0 & \\
\hline Glucose $\left(\mathrm{mmol} \mathrm{1}^{-1}\right)$ & $4.4 \pm$ & 1,0 & 4.0 & \pm & 1.2 & \\
\hline Amylase $\left(\mathrm{U}^{-1} 37^{\circ} \mathrm{C}\right)$ & $4.9 \pm$ & 2.7 & 2.8 & \pm & 2.2 & \\
\hline Cortisol (ng ml $\left.{ }^{-1}\right)$ & $10.5 \pm$ & $\pm \quad 8.4$ & 7.4 & \pm & 6.4 & \\
\hline
\end{tabular}

\begin{tabular}{|c|c|c|c|}
\hline Plasma parameters (7 months) & FO diet & EO diet & EF diet \\
\hline Cholesterol $\left(\mathrm{mmol} \mathrm{l}^{-1}\right)$ & $5.7 \pm$ & $6.2 \pm$ & $5.2 \pm$ \\
\hline Triglycerides $\left(\mathrm{mmol} \mathrm{l}^{-1}\right)$ & $3.2 \pm$ & $2.8 \pm$ & $3.1 \pm$ \\
\hline $\mathrm{GOT}-\mathrm{AST}\left(\mathrm{U}^{-1} 37^{\circ} \mathrm{C}\right)$ & $23.7 \pm$ & $22.9 \pm 10.7$ & $21.2 \pm$ \\
\hline $\mathrm{GPT}-\mathrm{ALT}\left(\mathrm{U} \mathrm{l}^{-1} 37^{\circ} \mathrm{C}\right)$ & $5.4 \pm$ & $3.4 \pm$ & $7.3 \pm$ \\
\hline $\operatorname{ALP}\left(\mathrm{U}^{-1} 37^{\circ} \mathrm{C}\right)$ & $353.4 \pm 151.2$ & $270.4 \pm 55.2$ & $348.8 \pm 120.0$ \\
\hline 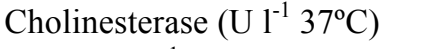 & $42.0 \pm 6.0$ & $39.7 \pm 5.1$ & $48.8 \pm 14.4$ \\
\hline Lipase $\left(\mathrm{U}^{-1} 37^{\circ} \mathrm{C}\right)$ & $60.0 \pm 22.0$ & $58.7 \pm 14.0$ & $72.0 \pm 14.0$ \\
\hline Protein $\left(\mathrm{g} \mathrm{l}^{-1}\right)$ & $35.3 \pm$ & $38.4 \pm 4.7$ & $35.8 \pm$ \\
\hline Glucose $\left(\mathrm{mmol} \mathrm{l}^{-1}\right)$ & $4.8 \pm$ & $3.9 \pm$ & $4.9 \pm$ \\
\hline Amylase $\left(\mathrm{U}^{-1} 37^{\circ} \mathrm{C}\right)$ & $2.2 \pm$ & $2.6 \pm$ & $2.3 \pm$ \\
\hline Cortisol (ng ml-1) & $45.8 \pm 34.0$ & $27.5 \pm 27.1$ & $59.0 \pm 19.5$ \\
\hline
\end{tabular}

Results represent means $\pm \mathrm{SD}(\mathrm{n}=6)$.

For 4 months, pairs of values within a given row which are significantly different $(\mathrm{P}<0.05)$ are shown $(*)$.

For 7 months, means within a given row bearing different letters are significantly different $(\mathrm{P}<0.05)$. EF:

EO-FO washout diet. 
Table 3. Total lipid (TL) contents and lipid class compositions ( $\mathrm{mg} \mathrm{g}^{-1} \mathrm{DWB}$ ) of muscle from gilthead seabream after 4 and 7 months of feeding with the FO, EO and EF (washout period of 3 months) diets.

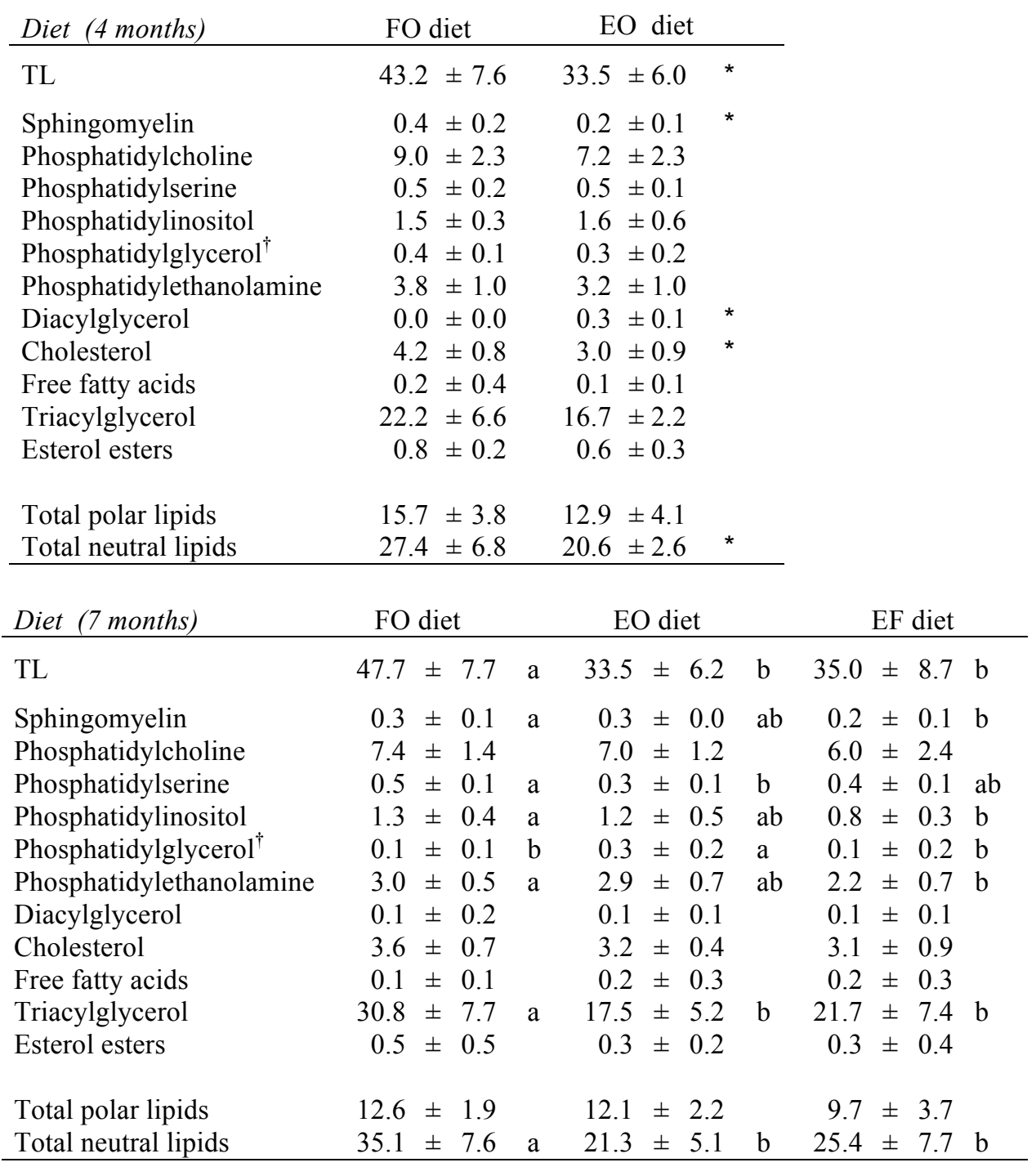

Results represent means $\pm \mathrm{SD}(\mathrm{n}=12)$.

Footnote as in Table 2. ${ }^{\dagger}$ May also include phosphatidic acid and cardiolipin. TL: Total lipid; DWB: Dry weight basis; EF: EO-FO washout diet. 
Table 4. Hepatosomatic Index (HSI), total lipid (TL) content and lipid class compositions (mg $\mathrm{g}^{-1}$ DWB) of liver from gilthead seabream after 4 and 7 months of feeding with the FO, EO and EF (washout period of 3 months) diets.

\begin{tabular}{|c|c|c|c|}
\hline Diet (4 months) & FO diet & EO diet & \\
\hline HSI & $1.18 \pm 0.3$ & $0.99 \pm$ & \\
\hline TL & $205.6 \pm 42.7$ & $193.5 \pm 46.4$ & \\
\hline Sphingomyelin & $2.3 \pm 0.9$ & $2.3 \pm$ & \\
\hline Phosphatidylcholine & $23.6 \pm 5.7$ & $33.0 \pm$ & \\
\hline Phosphatidylserine & $1.4 \pm 0.3$ & $1.8 \pm$ & \\
\hline Phosphatidylinositol & $6.4 \pm 1.7$ & $6.3 \pm$ & \\
\hline Phosphatidylglycerol $^{\dagger}$ & $4.4 \pm 1.6$ & $4.7 \pm$ & \\
\hline Phosphatidylethanolamine & $16.0 \pm 4.8$ & $17.2 \pm$ & \\
\hline Diacylglycerol & $0.0 \pm 0.0$ & $0.0 \pm$ & \\
\hline Cholesterol & $23.0 \pm 6.3$ & $25.7 \pm$ & \\
\hline Free fatty acids & $6.4 \pm 6.0$ & $9.4 \pm 2.81$ & \\
\hline Triacylglycerol & $116.6 \pm 33.6$ & $82.1 \pm$ & \\
\hline Esterol esters & $5.4 \pm 1.9$ & $9.9 \pm$ & $*$ \\
\hline Total polar lipids & $54.2 \pm 12.8$ & $66.4 \pm$ & \\
\hline Total neutral lipids & $151.4 \pm 33.7$ & $127.2 \pm$ & \\
\hline Diet (7 months) & FO diet & EO diet & EF diet \\
\hline HSI & $0.98 \pm 0.2 \mathrm{a}$ & $0.85 \pm 0.1 \mathrm{~b}$ & $0.99 \pm 0.1$ a \\
\hline TL & $269.7 \pm 48.6$ & $218.2 \pm 74.7$ & $220.4 \pm 32.4$ \\
\hline Sphingomyelin & $1.5 \pm 0.9$ & $1.2 \pm 0.3$ & $0.6 \pm 0.6$ \\
\hline Phosphatidylcholine & $22.5 \pm 7.5$ & $23.5 \pm 3.2$ & $26.5 \pm 1.1$ \\
\hline Phosphatidylserine & $1.1 \pm 1.0$ & $1.1 \pm 0.3$ & $1.4 \pm 0.4$ \\
\hline Phosphatidylinositol & $4.8 \pm 1.7$ & $4.4 \pm 1.1$ & $5.6 \pm 0.2$ \\
\hline Phosphatidylglycerol $^{\dagger}$ & $0.0 \pm 0.0$ & $0.0 \pm 0.0$ & $0.0 \pm 0.0$ \\
\hline Phosphatidylethanolamine & $13.9 \pm 4.4$ & $15.1 \pm 2.8$ & $17.9 \pm 0.7$ \\
\hline Diacylglycerol & $6.5 \pm 3.3$ & $4.4 \pm 1.6$ & $6.2 \pm 1.5$ \\
\hline Cholesterol & $15.4 \pm 5.6$ & $16.0 \pm 2.8$ & $17.5 \pm 0.9$ \\
\hline Free fatty acids & $11.8 \pm 6.0$ & $6.4 \pm 3.6$ & $9.8 \pm 2.0$ \\
\hline Triacylglycerol & $183.3 \pm 29.0$ & $130.0 \pm 61.3$ & $123.9 \pm 31.7$ \\
\hline Esterol esters & $8.9 \pm 2.4$ & $15.0 \pm 2.2$ & $10.6 \pm 4.5$ \\
\hline Total polar lipids & $43.8 \pm 14.5$ & $46.4 \pm 8.3$ & $52.4 \pm 2.7$ \\
\hline Total neutral lipids & $225.9 \pm 39.5$ & $171.8 \pm 69.0$ & $168.0 \pm 34.7$ \\
\hline
\end{tabular}

Results represent means \pm SD $(n=4)$.

Footnote as in Table 3. 
Table 5. Total fatty acid content ( $\left.\mathrm{mg} \mathrm{g}^{-1} \mathrm{DWB}\right)$ and composition (weight $\%$ ) of total lipids of muscle and liver from gilthead seabream after 4 months of feeding with the FO and EO diets.

\begin{tabular}{|c|c|c|c|c|c|c|c|c|c|c|c|c|}
\hline & \multicolumn{6}{|c|}{ Muscle } & \multicolumn{6}{|c|}{ Liver } \\
\hline & \multicolumn{2}{|l|}{ FO diet } & \multicolumn{3}{|c|}{ EO diet } & & \multicolumn{2}{|c|}{ FO diet } & \multicolumn{4}{|c|}{ EO diet } \\
\hline Total FA & $30.5=$ & \pm 7.4 & 25.5 & & 4.4 & & 176.8 & \pm 44.5 & 163.0 & \pm & 41.1 & \\
\hline $14: 0$ & $4.3 \pm$ & \pm 0.8 & 4.1 & \pm & 0.9 & & 5.0 & \pm 0.3 & 4.0 & \pm & 0.9 & \\
\hline $16: 0$ & $19.0 \pm$ & \pm 2.0 & 17.0 & \pm & 1.9 & $*$ & 19.0 & \pm 0.2 & 16.9 & \pm & 1.3 & * \\
\hline $16: 1^{1}$ & $7.2 \pm$ & \pm 1.0 & 6.1 & \pm & 1.2 & $*$ & 7.8 & \pm 0.4 & 5.5 & \pm & 0.8 & * \\
\hline 18:0 & $4.1 \pm$ & \pm 0.8 & 3.8 & \pm & 0.9 & & 4.8 & \pm 0.4 & 4.4 & \pm & 0.5 & \\
\hline $18: 1 \mathrm{n}-9$ & $17.0 \pm$ & \pm 1.5 & 17.0 & \pm & 0.9 & & 17.6 & \pm 0.5 & 17.9 & \pm & 0.6 & \\
\hline $18: 2 n-6$ & $4.9 \pm$ & \pm 0.7 & 7.5 & \pm & 0.8 & $*$ & 5.0 & \pm 0.4 & 8.8 & \pm & 1.2 & * \\
\hline $18: 3 n-6$ & $0.1 \pm$ & \pm 0.1 & 1.3 & \pm & 0.3 & $*$ & 0.1 & \pm 0.1 & 1.7 & \pm & 0.6 & $*$ \\
\hline $18: 3 n-3$ & $1.1 \pm$ & \pm 0.2 & 3.8 & \pm & 0.8 & $*$ & 1.2 & \pm 0.0 & 5.6 & \pm & 1.7 & * \\
\hline $18: 4 n-3$ & $1.5 \pm$ & \pm 0.3 & 2.0 & \pm & 0.5 & $*$ & 1.5 & \pm 0.2 & 2.0 & \pm & 0.3 & * \\
\hline $20: 1^{2}$ & $2.5 \pm$ & \pm 0.4 & 3.4 & \pm & 0.5 & $*$ & 1.8 & \pm 0.4 & 3.4 & \pm & 0.1 & * \\
\hline $20: 2 n-6$ & $0.2 \pm$ & \pm 0.0 & 0.2 & \pm & 0.0 & & 0.3 & \pm 0.0 & 0.4 & \pm & 0.1 & \\
\hline $20: 3 n-6$ & $0.1 \pm$ & \pm 0.1 & 0.4 & \pm & 0.1 & $*$ & 0.1 & \pm 0.1 & 0.9 & \pm & 0.0 & * \\
\hline $20: 4 n-6$ & $0.9 \pm$ & \pm 0.3 & 0.9 & \pm & 0.2 & & 0.9 & \pm 0.1 & 0.7 & \pm & 0.1 & \\
\hline $20: 3 n-3$ & $0.2 \pm$ & \pm 0.1 & 0.2 & \pm & 0.0 & & 0.2 & \pm 0.0 & 0.5 & \pm & 0.1 & * \\
\hline $20: 4 n-3$ & $0.9 \pm$ & \pm 0.1 & 0.8 & \pm & 0.1 & & 1.0 & \pm 0.0 & 1.1 & \pm & 0.2 & \\
\hline $20: 5 n-3$ & $7.4 \pm$ & \pm 0.5 & 5.7 & \pm & 0.7 & $*$ & 6.7 & \pm 0.6 & 4.3 & \pm & 0.6 & * \\
\hline $22: 1^{2}$ & $2.0 \pm$ & \pm 0.6 & 2.8 & \pm & 0.5 & $*$ & 1.5 & \pm 0.3 & 3.0 & \pm & 0.1 & \\
\hline $22: 5 n-3$ & $3.0 \pm$ & \pm 0.2 & 2.5 & \pm & 0.4 & $*$ & 3.1 & \pm 0.1 & 2.1 & \pm & 0.0 & $*$ \\
\hline $22: 6 n-3$ & $17.5 \pm$ & \pm 3.1 & 15.1 & \pm & 3.0 & & 15.7 & \pm 1.9 & 12.0 & \pm & 0.9 & * \\
\hline $24: 1 \mathrm{n}-9$ & $0.9 \pm$ & \pm 0.4 & 1.1 & \pm & 0.4 & & 0.8 & \pm 0.1 & 1.0 & \pm & 0.1 & * \\
\hline UK & $0.3 \pm$ & \pm 0.2 & 0.5 & \pm & 0.2 & & 0.5 & \pm 0.2 & 0.7 & \pm & 0.0 & \\
\hline Saturates & $28.7 \pm$ & \pm 2.4 & 25.9 & \pm & 2.2 & $*$ & 30.2 & \pm 0.9 & 26.4 & \pm & 2.2 & * \\
\hline Monoenes & $29.8 \pm$ & \pm 3.3 & 30.4 & \pm & 2.6 & & 29.6 & \pm 0.9 & 30.9 & \pm & 0.4 & \\
\hline$n-9$ & $18.0 \pm$ & \pm 1.5 & 18.1 & \pm & 1.0 & & 18.4 & \pm 0.4 & 18.9 & \pm & 0.7 & \\
\hline$n-3$ & $31.9 \pm$ & \pm 2.8 & 30.5 & \pm & 2.1 & & 29.9 & \pm 2.0 & 27.9 & \pm & 0.8 & \\
\hline$n-6$ & $6.7 \pm$ & \pm 0.8 & 10.7 & \pm & 1.1 & $*$ & 6.8 & \pm 0.3 & 12.7 & \pm & 2.0 & * \\
\hline n-3 HUFA & $29.2 \pm$ & \pm 3.1 & 24.5 & \pm & 2.9 & $*$ & 27.0 & \pm 2.1 & 20.4 & \pm & 1.2 & * \\
\hline$n-3 / n-6$ & $4.9 \pm$ & \pm 0.7 & 2.9 & \pm & 0.4 & $*$ & 4.4 & \pm 0.4 & 2.2 & \pm & 0.3 & $*$ \\
\hline 18:1/n-3 HUFA & $0.6 \pm$ & \pm 0.1 & 0.7 & \pm & 0.1 & $*$ & 0.7 & \pm 0.1 & 0.9 & \pm & 0.1 & * \\
\hline $\mathrm{AA} / \mathrm{EPA}$ & $0.1 \pm$ & \pm 0.0 & 0.2 & \pm & 0.0 & & 0.1 & \pm 0.0 & 0.2 & \pm & 0.0 & \\
\hline DHA/EPA & $2.4 \pm$ & \pm 0.4 & 2.7 & \pm & 0.7 & & 2.4 & \pm 0.3 & 2.8 & \pm & 0.2 & \\
\hline
\end{tabular}

Results represent means \pm SD ( $n=12$ for muscle and $n=4$ for liver). Pairs of values within a given row which are significantly different $(\mathrm{P}<0.05)$ are shown $(*)$. Totals include some minor components not shown. DWB: Dry weight basis. FA: fatty acids. UK: Unknown. ${ }^{1}$ Contains n-9 and n-7 isomers. ${ }^{2}$ Contains n-11 and n-9 isomers. 
Table 6. Total fatty acid content $\left(\mathrm{mg} \mathrm{g}^{-1} \mathrm{DWB}\right)$ and composition (\% weight) of total lipids of muscle from gilthead seabream after 7 months of feeding with the FO, EO and EF (washout period of 3 months) diets.

\begin{tabular}{|c|c|c|c|c|c|c|}
\hline & FO diet & & EO diet & & EF diet & \\
\hline Total FA & $37.8 \pm 6.7$ & $\mathrm{a}$ & $24.7 \pm 5.1$ & $\mathrm{~b}$ & $29.2 \pm 7.9$ & $\mathrm{~b}$ \\
\hline 14:0 & $5.3 \pm 0.7$ & $\mathrm{a}$ & $3.9 \pm 0.9$ & $\mathrm{~b}$ & $4.4 \pm 0.5$ & $\mathrm{~b}$ \\
\hline $16: 0$ & $18.5 \pm 2.1$ & $\mathrm{a}$ & $16.3 \pm 1.6$ & $\mathrm{~b}$ & $17.4 \pm 1.3$ & $a b$ \\
\hline $16: 1^{1}$ & $7.4 \pm 0.9$ & $\mathrm{a}$ & $5.3 \pm 1.0$ & $\mathrm{~b}$ & $6.4 \pm 0.5$ & $\mathrm{a}$ \\
\hline 18:0 & $3.5 \pm 0.4$ & & $3.6 \pm 0.6$ & & $3.3 \pm 0.5$ & \\
\hline $18: 1 \mathrm{n}-9$ & $15.5 \pm 1.7$ & & $15.1 \pm 1.5$ & & $15.7 \pm 0.8$ & \\
\hline $18: 2 n-6$ & $4.9 \pm 0.6$ & $\mathrm{c}$ & $9.0 \pm 0.3$ & $\mathrm{a}$ & $6.1 \pm 0.4$ & $\mathrm{~b}$ \\
\hline $18: 3 n-6$ & $0.1 \pm 0.1$ & $\mathrm{c}$ & $1.9 \pm 0.3$ & $\mathrm{a}$ & $0.7 \pm 0.3$ & $\mathrm{~b}$ \\
\hline $18: 3 n-3$ & $1.0 \pm 0.2$ & $\mathrm{c}$ & $5.5 \pm 0.8$ & $\mathrm{a}$ & $2.3 \pm 0.5$ & $\mathrm{~b}$ \\
\hline $18: 4 n-3$ & $1.4 \pm 0.2$ & $\mathrm{~b}$ & $2.0 \pm 0.3$ & $\mathrm{a}$ & $1.6 \pm 0.2$ & $\mathrm{~b}$ \\
\hline $20: 1^{2}$ & $4.2 \pm 0.6$ & $\mathrm{~b}$ & $4.1 \pm 0.4$ & $\mathrm{~b}$ & $5.0 \pm 0.5$ & $\mathrm{a}$ \\
\hline $20: 2 n-6$ & $0.2 \pm 0.0$ & $\mathrm{~b}$ & $0.3 \pm 0.0$ & $\mathrm{a}$ & $0.3 \pm 0.0$ & $\mathrm{a}$ \\
\hline $20: 3 n-6$ & $0.0 \pm 0.0$ & $\mathrm{c}$ & $0.5 \pm 0.1$ & $\mathrm{a}$ & $0.2 \pm 0.0$ & $\mathrm{~b}$ \\
\hline $20: 4 n-6$ & $0.6 \pm 0.1$ & & $0.7 \pm 0.2$ & & $0.6 \pm 0.1$ & \\
\hline $20: 3 n-3$ & $0.0 \pm 0.0$ & $\mathrm{~b}$ & $0.2 \pm 0.1$ & $\mathrm{a}$ & $0.1 \pm 0.1$ & $\mathrm{~b}$ \\
\hline $20: 4 n-3$ & $0.9 \pm 0.1$ & & $0.8 \pm 0.1$ & & $0.9 \pm 0.1$ & \\
\hline $20: 5 n-3$ & $6.4 \pm 0.9$ & $\mathrm{a}$ & $4.3 \pm 0.5$ & $\mathrm{c}$ & $5.3 \pm 0.4$ & $\mathrm{~b}$ \\
\hline $22: 1^{2}$ & $3.8 \pm 0.6$ & $\mathrm{~b}$ & $3.5 \pm 0.6$ & $\mathrm{~b}$ & $4.6 \pm 0.5$ & $\mathrm{a}$ \\
\hline $22: 5 n-3$ & $2.6 \pm 0.1$ & $\mathrm{a}$ & $1.8 \pm 0.2$ & $\mathrm{~b}$ & $2.4 \pm 0.2$ & $\mathrm{a}$ \\
\hline $22: 6 n-3$ & $13.2 \pm 1.6$ & & $13.1 \pm 3.2$ & & $13.7 \pm 1.6$ & \\
\hline $24: 1 \mathrm{n}-9$ & $0.7 \pm 0.1$ & $\mathrm{~b}$ & $0.9 \pm 0.1$ & $\mathrm{a}$ & $0.8 \pm 0.1$ & $\mathrm{a}$ \\
\hline UK & $1.2 \pm 0.3$ & & $1.0 \pm 0.6$ & & $1.0 \pm 0.4$ & \\
\hline Saturates & $27.9 \pm 2.1$ & $\mathrm{a}$ & $24.2 \pm 1.6$ & $\mathrm{~b}$ & $25.7 \pm 1.5$ & $\mathrm{~b}$ \\
\hline Monoenes & $51.8 \pm 6.8$ & $\mathrm{ab}$ & $48.1 \pm 3.5$ & $\mathrm{~b}$ & $54.2 \pm 2.6$ & $\mathrm{a}$ \\
\hline$n-9$ & $24.3 \pm 2.4$ & $\mathrm{ab}$ & $23.5 \pm 2.3$ & $\mathrm{~b}$ & $26.2 \pm 1.5$ & $\mathrm{a}$ \\
\hline$n-3$ & $27.0 \pm 1.9$ & & $28.7 \pm 2.5$ & & $27.3 \pm 1.7$ & \\
\hline$n-6$ & $6.6 \pm 0.6$ & $\mathrm{c}$ & $12.7 \pm 0.5$ & $\mathrm{a}$ & $8.5 \pm 0.7$ & $\mathrm{~b}$ \\
\hline n-3 HUFA & $23.3 \pm 2.2$ & & $20.3 \pm 3.4$ & & $22.5 \pm 1.8$ & \\
\hline$n-3 / n-6$ & $4.1 \pm 0.5$ & $\mathrm{a}$ & $2.3 \pm 0.2$ & $\mathrm{c}$ & $3.2 \pm 0.3$ & $\mathrm{~b}$ \\
\hline 18:1/n-3 HUFA & $0.8 \pm 0.1$ & & $0.9 \pm 0.2$ & & $0.8 \pm 0.1$ & \\
\hline AA/EPA & $0.1 \pm 0.0$ & $\mathrm{~b}$ & $0.2 \pm 0.0$ & $\mathrm{a}$ & $0.1 \pm 0.0$ & $\mathrm{~b}$ \\
\hline DHA/EPA & $2.1 \pm 0.2$ & $\mathrm{~b}$ & $3.1 \pm 0.6$ & $\mathrm{a}$ & $2.6 \pm 0.3$ & $\mathrm{a}$ \\
\hline
\end{tabular}

Results represent means $\pm \mathrm{SD}(\mathrm{n}=12)$. Means within a given row bearing different letters are significantly different $(\mathrm{P}<0.05)$. Totals include some minor components not shown. DWB: Dry weight basis. EF: EO-FO washout diet. FA: fatty acids. UK: Unknown. ${ }^{1}$ Contains n-9 and n-7 isomers. ${ }^{2}$ Contains n-11 and n-9 isomers. 
Table 7. Total fatty acid content $\left(\mathrm{mg} \mathrm{g}^{-1} \mathrm{DWB}\right)$ and composition (\% weight) of total lipids of liver from gilthead seabream after 7 months of feeding with the FO, EO and EF (washout period of 3 months) diets.

\begin{tabular}{|c|c|c|c|c|c|c|c|c|c|}
\hline \multirow[b]{2}{*}{ Total FA } & \multicolumn{2}{|l|}{ FO diet } & \multicolumn{4}{|c|}{ EO diet } & \multicolumn{3}{|c|}{ EF diet } \\
\hline & $195.4 \pm 34.5$ & & 163.8 & \pm & 72.9 & & 191.5 & \pm 55.0 & \\
\hline $14: 0$ & $4.8 \pm 0.4$ & & 3.8 & \pm & 0.3 & & 4.2 & \pm 0.5 & \\
\hline $16: 0$ & $18.1 \pm 0.5$ & $\mathrm{a}$ & 15.7 & \pm & 0.3 & $\mathrm{~b}$ & 18.4 & \pm 1.1 & $\mathrm{a}$ \\
\hline $16: 1^{1}$ & $7.3 \pm 0.3$ & $\mathrm{a}$ & 5.1 & \pm & 0.5 & $\mathrm{c}$ & 6.4 & \pm 0.3 & $\mathrm{~b}$ \\
\hline 18:0 & $4.2 \pm 0.2$ & & 3.8 & \pm & 0.2 & & 4.5 & \pm 0.5 & \\
\hline $18: 1 \mathrm{n}-9$ & $20.9 \pm 1.8$ & & 17.6 & \pm & 0.5 & & 20.7 & \pm 0.6 & \\
\hline $18: 2 n-6$ & $5.2 \pm 0.0$ & $\mathrm{~b}$ & 10.1 & \pm & 0.2 & $\mathrm{a}$ & 5.7 & \pm 0.6 & $\mathrm{~b}$ \\
\hline $18: 3 n-6$ & $0.0 \pm 0.0$ & $\mathrm{c}$ & 2.5 & \pm & 0.1 & $\mathrm{a}$ & 0.3 & \pm 0.2 & $\mathrm{~b}$ \\
\hline $18: 3 n-3$ & $1.1 \pm 0.1$ & $\mathrm{~b}$ & 7.7 & \pm & 0.4 & $\mathrm{a}$ & 1.6 & \pm 0.5 & $\mathrm{~b}$ \\
\hline $18: 4 n-3$ & $1.3 \pm 0.2$ & $\mathrm{~b}$ & 2.5 & \pm & 0.1 & $\mathrm{a}$ & 1.1 & \pm 0.3 & $\mathrm{~b}$ \\
\hline $20: 1^{2}$ & $4.9 \pm 0.4$ & & 4.3 & \pm & 0.2 & & 4.9 & \pm 0.5 & \\
\hline $20: 2 n-6$ & $0.3 \pm 0.0$ & & 0.3 & \pm & 0.1 & & 0.4 & \pm 0.0 & \\
\hline $20: 3 n-6$ & $0.0 \pm 0.0$ & $\mathrm{~b}$ & 0.7 & \pm & 0.1 & $\mathrm{a}$ & 0.2 & \pm 0.0 & $\mathrm{~b}$ \\
\hline $20: 4 n-6$ & $0.6 \pm 0.1$ & & 0.6 & \pm & 0.1 & & 0.7 & \pm 0.1 & \\
\hline $20: 3 n-3$ & $0.2 \pm 0.0$ & $\mathrm{~b}$ & 0.4 & \pm & 0.1 & $\mathrm{a}$ & 0.2 & \pm 0.0 & $\mathrm{~b}$ \\
\hline $20: 4 n-3$ & $1.1 \pm 0.1$ & & 1.1 & \pm & 0.1 & & 1.1 & \pm 0.1 & \\
\hline $20: 5 n-3$ & $5.2 \pm 0.5$ & $\mathrm{a}$ & 3.7 & \pm & 0.4 & $\mathrm{~b}$ & 4.5 & \pm 0.2 & $\mathrm{a}$ \\
\hline $22: 1^{2}$ & $4.6 \pm 0.5$ & $\mathrm{a}$ & 3.8 & \pm & 0.3 & $\mathrm{~b}$ & 4.4 & \pm 0.3 & $a b$ \\
\hline $22: 5 n-3$ & $3.2 \pm 0.2$ & $\mathrm{a}$ & 1.8 & \pm & 0.2 & $\mathrm{~b}$ & 3.3 & \pm 0.4 & $\mathrm{a}$ \\
\hline $22: 6 n-3$ & $11.5 \pm 1.0$ & $\mathrm{ab}$ & 10.1 & \pm & 0.3 & $\mathrm{~b}$ & 12.3 & \pm 0.6 & $\mathrm{a}$ \\
\hline $24: 1 \mathrm{n}-9$ & $0.7 \pm 0.3$ & & 0.7 & \pm & 0.2 & & 0.6 & \pm 0.2 & \\
\hline UK & $0.9 \pm 0.3$ & & 1.3 & \pm & 0.6 & & 1.5 & \pm 0.4 & \\
\hline Saturates & $28.2 \pm 0.7$ & $\mathrm{a}$ & 24.1 & \pm & 0.7 & $\mathrm{~b}$ & 28.0 & \pm 1.2 & $\mathrm{a}$ \\
\hline Monoenes & $38.4 \pm 2.0$ & $\mathrm{a}$ & 31.5 & \pm & 0.3 & $\mathrm{~b}$ & 37.1 & \pm 0.4 & $\mathrm{a}$ \\
\hline$n-9$ & $21.7 \pm 1.8$ & $a b$ & 18.4 & \pm & 0.3 & $\mathrm{~b}$ & 21.5 & \pm 0.8 & $\mathrm{a}$ \\
\hline$n-3$ & $23.9 \pm 1.7$ & $\mathrm{~b}$ & 27.5 & \pm & 0.5 & $\mathrm{a}$ & 24.4 & \pm 0.4 & $\mathrm{~b}$ \\
\hline$n-6$ & $6.7 \pm 0.1$ & $\mathrm{c}$ & 14.5 & \pm & 0.5 & $\mathrm{a}$ & 7.7 & \pm 0.7 & $\mathrm{~b}$ \\
\hline n-3 HUFA & $21.4 \pm 1.5$ & $\mathrm{a}$ & 16.9 & \pm & 0.8 & $\mathrm{~b}$ & 21.6 & \pm 0.7 & $\mathrm{a}$ \\
\hline$n-3 / n-6$ & $3.6 \pm 0.3$ & $\mathrm{a}$ & 1.9 & \pm & 0.1 & $\mathrm{~b}$ & 3.2 & \pm 0.3 & $\mathrm{a}$ \\
\hline 18:1/n-3 HUFA & $1.0 \pm 0.1$ & & 1.0 & \pm & 0.0 & & 1.0 & \pm 0.0 & \\
\hline $\mathrm{AA} / \mathrm{EPA}$ & $0.1 \pm 0.0$ & $\mathrm{~b}$ & 0.2 & \pm & 0.0 & $\mathrm{a}$ & 0.2 & \pm 0.0 & $a b$ \\
\hline DHA/EPA & $2.2 \pm 0.1$ & $\mathrm{~b}$ & 2.7 & \pm & 0.2 & $\mathrm{a}$ & 2.7 & \pm 0.2 & $\mathrm{a}$ \\
\hline
\end{tabular}

Results represent means $\pm \mathrm{SD}(\mathrm{n}=4)$.

Footnote as in Table 6. 
Fig.1

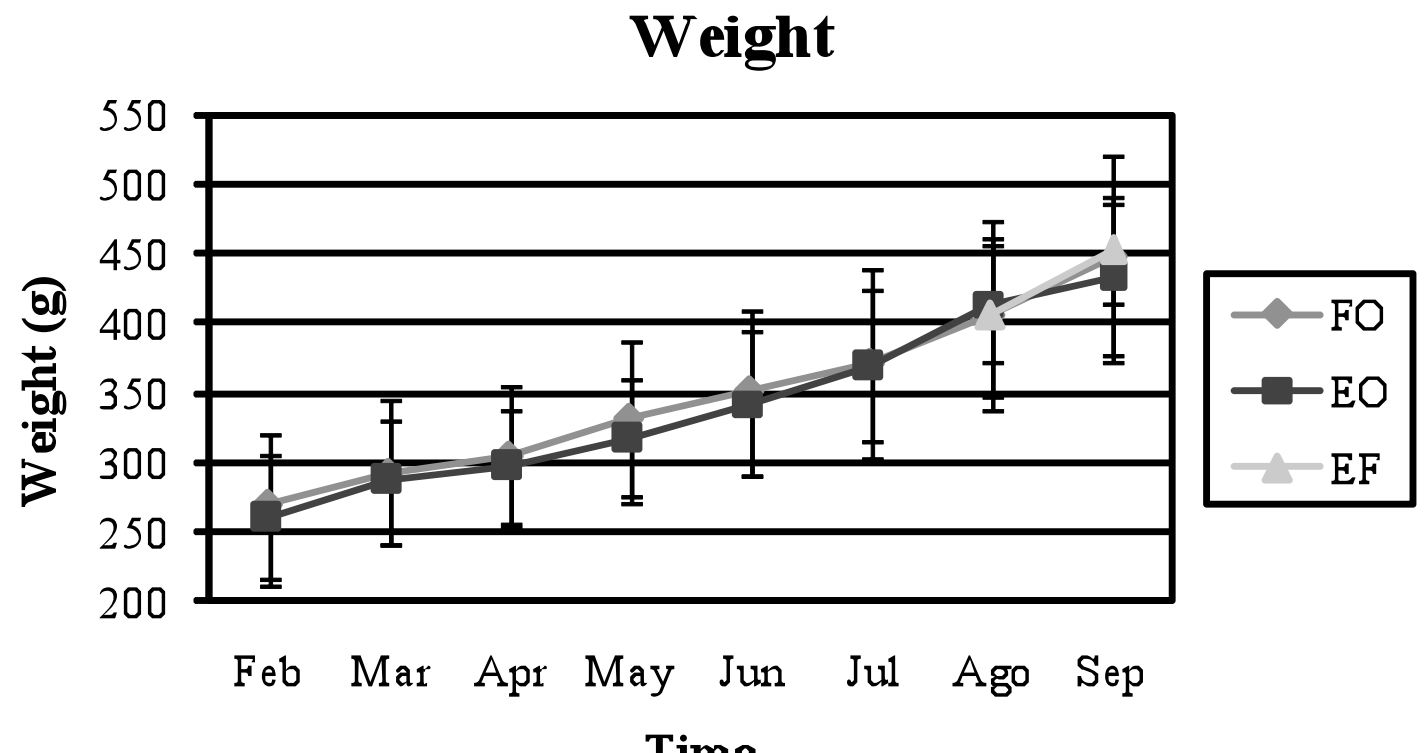

Time

Size

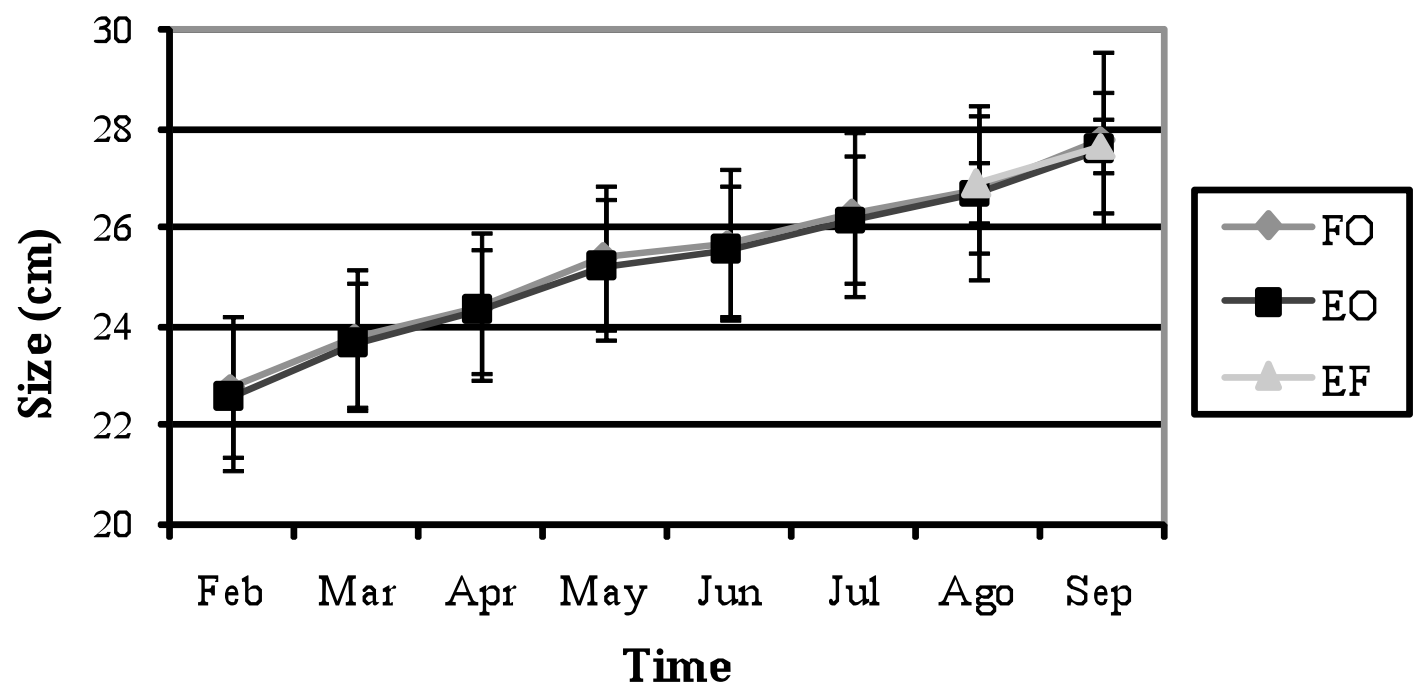




\section{Legends to Figures:}

Fig.1. Growth along the experimental period of fish fed with the FO, EO and EF (washout period of 3 months) diets. Results are means \pm SD (20-30). 